\title{
Local government debt risk measurement and early warning structural system building -- Research Based on KMV and TOPSIS Models
}

\author{
Rongzhou Zhang ${ }^{1}$, Ruoyu Shi ${ }^{1}$, Cheng Li $^{1}$ \\ ${ }^{1}$ Tianjin Polytechnic University, Jiangsu, China
}

\begin{abstract}
In this paper, by using the Statistical analysis Software SPSS20, 30 and Cities of our country's local government structural debt risk has been carried on the empirical analysis, using the entropy weight method to determine the specific weight of each index, reduced the subjective factors of influence on the result of the index weight distribution, expectations of local government debt defaults and the situation of the comprehensive evaluation index of local government debt. By comparing the size of the threshold value, to determine the risk of local government debt, the results show that in 7 provinces and cities in China are in the state of no warning of local debt risk, in 10 provinces and cities are in the state of mild warning. Means and Cities are in the State of Moderate warning, In other words, it means it's time to generate the risk of local government debt. In the State of high warning, most means and cities need to take scientific measures to generate the risk of local government debt.
\end{abstract}

\section{Introduction}

Since the 2008 financial crisis, local governments in order to promote the rapid development of local economy, investment in the field of infrastructure and other public livelihood of the people increasing and debt scale expands rapidly, once the accumulated debt risk is higher than the actual capacity of local government, local government will face the severe credit crisis, and even lead to a regional financial crisis, so the local government financial risk early warning research is of great significance.

Debt risk has become the high frequency words in recent years, the central file, convey the central management of the importance of local government debt risk, including the State Council on strengthening the opinions of the local government debt management "(guo fa [2014] no. 43 file) is considered to be the signature of the debt of local government reform process file, the file identified by snookering, clear responsibility for the principle, control of local government debt, used for the construction of local government debt management mechanism of local government debt risk control and gradually resolved. $1 \mathrm{In}$ the report to the 19th National Congress of the COMMUNIST Party of China (CPC), it was proposed to improve China's financial supervision system and strictly guard against systemic financial risks.2In December 2019, the National Financial Work Conference emphasized "making good use of special bonds issued by local governments, standardizing local governments' behavior of borrowing and financing, and preventing and defusing hidden debt risks of local governments".

Combined with the above background, the construction of local government debt structural risk early warning system can predict the development of local government debt risk in advance, so as to timely take necessary measures to control the risk in a tolerable range and avoid systemic risks.In this paper, the situation of local government debt in 30 provinces and cities is analyzed. Based on the comprehensive evaluation index method, the expected default rate of local government debt is introduced for comprehensive evaluation, and the specific weight of evaluation index is calculated by entropy weight method, so as to objectively and reasonably reflect the risk of local government debt.

\section{The construction of local government debt risk early warning system}

\subsection{Constructing ideas}

In order to reflect and predict the risks of local government debt risk early warning system, and then realize the goal of eliminating risks in a timely manner, it is necessary to evaluate the situation of local government debt after having an objective understanding [9]. Therefore, in the selection of evaluation indicators, attention should be paid to the sensitivity and practicability of evaluation indicators 
for local government debt risks, and careful selection should be made. According to the principle of classified disposal of governmental debt risk events stipulated in document No. 88 of the State Council [2016], different treatment mechanisms should be adopted for the degree of debt risk[10].

Based on the existing research results on local government debt risk, the warning degree of local government debt risk is divided into three levels: light level, medium level and high level. The warning range threshold is set to directly reflect the risk level of local government debt risk in different provinces and cities.

\subsection{Model construction}

\subsubsection{Select early warning indicators}

In view of the complex factors affecting local government debt risk, this paper selects indicators from three aspects: economic development status, financial status and debt status.

Indicator selection at the level of economic development: the fundamental driving force of local government borrowing is to promote the development of regional economy, and the development degree of local economy is also an important factor to measure the level of local government debt[11]. Generally speaking, when the level of regional economic development is high, local governments have more sufficient sources of fiscal revenue and higher solvency. Conversely, it will depress the level of local government debt repayment. Referring to the common practice of domestic and foreign scholars, this paper selects economic growth rate, per capita GDP and fixed asset investment rate growth rate to represent the development level of regional economy.

Three indicators are selected from the level of local government financial revenue and expenditure. Fiscal revenue elasticity is the ratio of income growth rate and GDP growth rate. It is generally believed that the ratio above 1 indicates that local governments have higher financial capacity and faster solvency. Expenditure elasticity is the ratio between the growth rate of fiscal expenditure and GDP growth rate. The larger the result is, the weaker the solvency of local governments is. The deficit ratio refers to the ratio of fiscal deficit to GDP. The higher the ratio, the greater the risk of local government debt.

At the level of local government debt, three indicators are selected: the comprehensive debt ratio is the ratio of the sum of explicit and implicit debt balance to GDP. The smaller the value is, the less the debt risk of local government will be.The ratio of debt balance to fiscal revenue can reflect the relative scale of local government debt and fiscal revenue. The smaller the value, the less the debt risk. The expected debt default rate is derived from the KMV model, and the internationally recognized standard is used to refer to the expected default rate of local government bonds rated as $\mathrm{BBB}+$ by Standard \& Poor's or Baal by Moody's, which is lower than $0.4 \%$, with a small default risk[12].

\subsubsection{Determine the weight of early warning indicators}

In order to reduce the effect of subjective factor on the results of the analysis, this paper selects the entropy weight method to determine the index weight, will first to dimensionless index data collected by the standardization, standardization of data processing by applying the method of extremum, assumes that the evaluation model of the communist party of China has a indicators, namely, one is evaluation objects, namely, the local government Xi under the index value is to standardize the value of the type (1).

$$
\begin{aligned}
& n A_{1}, A_{2}, \cdots A_{n} X_{1}, X_{2} \cdots X_{m} A_{\mathrm{j}} X i j Y i j \\
& y_{i j}=\left(x_{i j}-\min \left(x_{i j}\right)\right) /\left(\max \left(x_{i j}\right)-\min \left(x i_{j}\right)\right)
\end{aligned}
$$

Next, the index is normalized. The relative proportion of the index in the first local government index is,

(Equation 2). ${ }^{A_{j}} i y_{i j} \mathrm{p}_{i j}$

$$
p_{i j}=y_{i j} / \sum y_{i j}
$$

Then, calculate the entropy value of each indicator (Formula 3) :

$$
e_{j}=-k \sum p_{i j} \ln p i_{j}
$$

Among them: $\mathrm{k}=1 / \ln m$

Derivation of the difference coefficient of the item (Formula 4) $: \mathrm{j}^{g_{j}}$

$$
\mathrm{g}_{i}=1-e_{j}
$$

Finally, the weight of each indicator is obtained (Formula 5) : ${ }^{W_{j}}$

$$
\mathrm{w}_{j}=g_{j} / \sum g_{j}
$$

\subsubsection{Calculate the comprehensive evaluation index}

TOPSIS is a highly effective method in solving multiobjective decision-making problems. By calculating the positive and negative ideal solutions of the evaluation objects, the degree of proximity between the evaluation indexes and the positive and negative ideal solutions is obtained, and then the pros and cons are evaluated[5]. If the distance between the evaluation object and the positive and negative ideal solution is, and the ranking index value of the evaluation object is, then the comprehensive evaluation index of the evaluation object is, the larger the value is, the smaller the debt risk of the local government is. $A_{i} B_{\mathrm{i}} k_{i}=A_{\mathrm{i}} /\left(A_{\mathrm{i}}+B_{i}\right) E_{i}=k_{i} \times E E_{i}$ In accordance with the principle of caution, the following classification is made:. $k_{i} k_{i} \in[0.9,+\infty], \mathrm{k}_{i} \in[0.8,0.9], k_{i} \in[0,0.8]$ When the value of is close to an integer, the risk status of local government debt represents green, red and yellow lights. $E E_{i} E_{i} E i \in[4.5,+\infty] 、 E_{\mathrm{i}} \in[4,4.5] 、 E_{\mathrm{i}} \in[0,4]$

According to the expected default rate of local government debt and the comprehensive evaluation index, the warning situation of local government debt risk is divided into four levels, namely, when the expected default rate is below $0.4 \%$ and the state of the composite index is green, the risk control of local government debt is good and there is no warning situation. When the expected 
debt default rate is less than $0.4 \%$ but the composite index status is yellow, it indicates that the local government debt is in a mild warning status. Although there are risks, they have not yet developed to the extent that they will affect the normal operation of local finance and economy. When the expected debt default rate is lower than $0.4 \%$ and the state of the composite index is at a red light, it indicates that the risk of local government debt has been moderately warned, and relevant departments should take measures to properly deal with it. When the expected debt default rate is higher than $0.4 \%$, no matter what state the composite index is in, it indicates that the local government debt risks are serious, and if mishandled, it will cause the local government credit crisis.

\section{Empirical analysis of local government debt risk early warning}

\subsection{Data sources}

The research data in this paper are mainly obtained from the Wind database, the statistical bulletin of social and economic Development of local governments, the website of the Budget Department of the Ministry of Finance and the website of the National Bureau of Statistics of China. Some of the data are collected and calculated, and the implicit debt scale is estimated by referring to the classification method of $\mathrm{Li}$ Lizhen and An Xiumei (2019)[5].

\subsection{Estimates of default rates}

Considering the estimated 2018 the local government debt default rate of incomplete data, this article selects the 2017 data of 30 provinces and cities of the country's debt defaults in the estimate (except Tibet region due to the geographical environment), published in 2017 fiscal revenue of local government, it is concluded that local government debt default distance of 30 provinces and cities and make an appointment to defaults, see table 1 .

Table1. Distance of provincial and municipal government debts and expected default rates

\begin{tabular}{|l|l|l|l|}
\hline $\begin{array}{l}\text { The index } \\
\text { type }\end{array}$ & $\begin{array}{l}\text { The index } \\
\text { name }\end{array}$ & Indicators show & meaning \\
\hline $\begin{array}{l}\text { Indicators at } \\
\text { the level of } \\
\text { economic } \\
\text { development }\end{array}$ & $\begin{array}{l}\text { Economic } \\
\text { growth }\end{array}$ & $\begin{array}{l}\text { GDP per } \\
\text { capita }\end{array}$ & $\begin{array}{l}\text { The higher the index } \\
\text { value, the higher the } \\
\text { level of regional } \\
\text { economic development, } \\
\text { the more abundant the } \\
\text { source of fiscal revenue } \\
\text { of local governments, } \\
\text { the higher the solvency }\end{array}$ \\
\hline $\begin{array}{l}\text { investment } \\
\text { rate growth } \\
\text { of local } \\
\text { government } \\
\text { revenue and } \\
\text { expenditure }\end{array}$ & $\begin{array}{l}\text { Fiscal } \\
\text { revenue } \\
\text { elasticity }\end{array}$ & $\begin{array}{l}\text { Income growth } \\
\text { rate /GDP } \\
\text { growth rate }\end{array}$ & $\begin{array}{l}\text { If the ratio is higher } \\
\text { than 1, it means that } \\
\text { local governments have } \\
\text { higher financial } \\
\text { capacity and faster } \\
\text { solvency }\end{array}$ \\
\cline { 2 - 3 } & $\begin{array}{l}\text { Spending on } \\
\text { elastic }\end{array}$ & $\begin{array}{l}\text { Growth rate of } \\
\text { fiscal } \\
\text { expenditure } \\
\text { /GDP growth } \\
\text { rate }\end{array}$ & $\begin{array}{l}\text { The bigger the result, } \\
\text { the weaker the solvency } \\
\text { of local governments }\end{array}$ \\
\hline
\end{tabular}

\begin{tabular}{|c|c|c|c|}
\hline & deficit & $\begin{array}{l}\text { Fiscal deficit } \\
\text { /GDP }\end{array}$ & $\begin{array}{l}\text { The higher the value, } \\
\text { the greater the risk of } \\
\text { local government debt }\end{array}$ \\
\hline \multirow[t]{3}{*}{$\begin{array}{l}\text { An indicator } \\
\text { of local } \\
\text { government } \\
\text { debt }\end{array}$} & $\begin{array}{l}\text { Comprehens } \\
\text { ive liability } \\
\text { ratio }\end{array}$ & $\begin{array}{l}\text { Explicit debt }+ \\
\text { implicit debt } \\
\text { /GDP }\end{array}$ & $\begin{array}{l}\text { The smaller the value, } \\
\text { the lower the overall } \\
\text { debt risk of local } \\
\text { governments }\end{array}$ \\
\hline & $\begin{array}{l}\text { The relative } \\
\text { size of debt } \\
\text { and revenue }\end{array}$ & $\begin{array}{l}\text { Debt } \\
\text { balance/revenue }\end{array}$ & $\begin{array}{l}\text { The smaller the } \\
\text { number, the lower the } \\
\text { risk of debt }\end{array}$ \\
\hline & $\begin{array}{l}\text { Expected } \\
\text { default rate } \\
\text { PT }\end{array}$ & 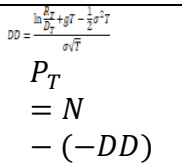 & $\begin{array}{l}\text { Less than } 0.4 \text { per cent } \\
\text { means less risk of } \\
\text { default }\end{array}$ \\
\hline
\end{tabular}

As can be seen from Table 1, the lower the proportion of financial funds that can be used to repay debts in local government fiscal revenue, the higher the expected default rate will be. At 20 per cent, four provinces -- Guizhou, Qinghai, Yunnan and Liaoning -- are expected to have default rates higher than 0.4 per cent, while the rest are within the safety line. Heilongjiang, Jilin, Hubei, Guangxi and Hainan were added to the list of provinces where local government debt defaults are expected to be higher than 0.4 per cent at 15 per cent. At $10 \%$, except for Beijing, Shanghai and Guangzhou, Jiangsu and Zhejiang, fujian and Shandong, which have a high level of economic development, the default rate of all other provinces is higher than $0.4 \%$, presenting a large debt risk. According to the results, the solvency of 30 provincial and municipal governments was divided into three levels, namely, first level, second level and third level.

Combined with the actual situation of local government debt in China, the proportion of $20 \%$ is more consistent with actual situation, and on the basis of Wind database query results, in recent years, the majority of the local government fiscal expenditure rigidity control under $70 \%$, means that $30 \%$ of the fiscal expenditure can be compressed to repay the debt of local government, but also want to consider in this paper, the analysis of the debt data selection in 2017, since 2017 the local government debt will be part of the new data, so this article calculate the expected default rate than the actual situation, should not relax vigilance of local government debt.

\subsection{Calculation of comprehensive evaluation index}

The expected default rate reflects one aspect of local government debt risk, which cannot be comprehensively reflected. It should be combined with the comprehensive evaluation index to reflect the local government debt risk more comprehensively and objectively. In this paper, the method based on entropy weight method is used to calculate the comprehensive evaluation index of local government debt risk. The results are shown in Table 2.

Table2. Evaluation results of comprehensive indicators of each province

\begin{tabular}{|c|c|c|c|c|c|}
\hline $\begin{array}{c}\text { The evaluation } \\
\text { object }\end{array}$ & $\begin{array}{c}\text { Evaluation } \\
\text { composite } \\
\text { index }\end{array}$ & state & $\begin{array}{c}\text { The evaluation } \\
\text { object }\end{array}$ & $\begin{array}{c}\text { Evaluation } \\
\text { composite } \\
\text { index }\end{array}$ & state \\
\hline Beijing & 4.578 & A green light & henan & 4.252 & Yellow light \\
\hline tianjin & 4.509 & A green light & hubei & 4.267 & Yellow light \\
\hline
\end{tabular}




\begin{tabular}{|c|c|c|c|c|c|}
\hline hebei & 4.267 & Yellow light & hunan & 4.274 & Yellow light \\
\hline shanxi & 4.198 & Yellow light & guangdong & 4.542 & A green light \\
\hline Inner Mongolia & 3.496 & A red light & guangxi & 4.195 & Yellow light \\
\hline liaoning & 3.047 & A red light & hainan & 3.489 & A red light \\
\hline Ji Lin & 4.176 & Yellow light & chongqing & 4.183 & Yellow light \\
\hline heilongjiang & 3.693 & A red light & sichuan & 4.178 & Yellow light \\
\hline Shanghai & 4.798 & A green light & guizhou & 3.276 & A red light \\
\hline jiangsu & 4.582 & A green light & yunnan & 3.553 & A red light \\
\hline zhejiang & 3.267 & Yellow light & shaanxi & 4.115 & Yellow light \\
\hline anhui & 3.185 & Yellow light & gansu & 3.275 & A red light \\
\hline fujian & 4.526 & A green light & qinghai & 3.108 & A red light \\
\hline jiangxi & 4.146 & Yellow light & ningxia & 3.495 & A red light \\
\hline shandong & 4.535 & A green light & xinjiang & 3.865 & A red light \\
\hline
\end{tabular}

As can be seen from Table 2, among the 30 provinces and cities in this study, 7 of them are in the green state, 13 in the yellow state and 10 in the red state, accounting for $23.33 \%, 46.67 \%, 33.33 \%$ and $43.33 \%$ respectively.

\subsection{Results of early warning on local government debt risks}

Combined with the calculation results of the expected debt default rate of local governments (based on the principle of prudence, the calculation results under the ratio of $15 \%$ ) and the comprehensive evaluation index of debt risk, and based on the risk warning standard mentioned above, the risk levels of local government debt risks in 30 provinces and cities studied in this study are classified. The results are shown in Table 3.

Table3. Early warning results of provincial and municipal government debt risks

\begin{tabular}{|c|c|c|c|}
\hline $\begin{array}{l}\text { The evaluation } \\
\text { object. }\end{array}$ & The warning type & The evaluation object & The warning type \\
\hline $\begin{array}{l}\text { Beijing } \\
\text { tianjin }\end{array}$ & \multirow{3}{*}{ No warning } & $\begin{array}{l}\text { sichuan } \\
\text { shaanxi }\end{array}$ & Mild warning \\
\hline $\begin{array}{l}\text { Shanghai } \\
\text { jiangsu }\end{array}$ & & $\begin{array}{l}\text { gansu } \\
\text { ningxia } \\
\text { xinjiang }\end{array}$ & Moderate warning \\
\hline $\begin{array}{l}\text { fujlan } \\
\text { shandong } \\
\text { guangdong }\end{array}$ & & $\begin{array}{l}\text { Inner Mongolia } \\
\text { liaoning } \\
\text { Ji Lin }\end{array}$ & \\
\hline $\begin{array}{l}\text { hebei } \\
\text { shanxi } \\
\text { zhejiang } \\
\text { anhui } \\
\text { jiangxi } \\
\text { henan } \\
\text { hunan } \\
\text { chongqing }\end{array}$ & Mild warning & \begin{tabular}{|l} 
heilongjiang \\
hubei \\
guangxi \\
hainan \\
guizhou \\
yunnan \\
qinghai
\end{tabular} & Highly alert \\
\hline
\end{tabular}

As can be seen from Table 3, among the 30 provinces and cities, 7 of them are in a non-warning state, 10 in a mild warning state, 3 in a moderate warning state and 10 in a high warning state, accounting for $23.33 \%, 33.33 \%$, $10 \%$ and $33.33 \%$ respectively.

\section{Countermeasures and Suggestions for early warning management of local government debt risks}

\subsection{Further strengthen the disclosure of local government debt information}

First of all, local governments can disclose the debt scale, debt repayment structure, debt default and other information in the form of reports. At the same time, the nature of each type of debt and the contingent debt should be explained in the report. Secondly, local governments should disclose financial information that can be used to repay debts. The financial revenue of local governments is a direct response to the financial resources of local governments, and local governments with higher financial revenue have deeper financial resources. However, local governments need to set aside some funds to manage public affairs or build public utilities because their fiscal revenue is widely invested. Only some funds can be set aside for debt repayment. Therefore, regular disclosure of local government financial resources that can be repaid can better analyze local government debt repayment ability and the remaining borrowing space, and realize effective monitoring of debt risk. At present, the financial information disclosure standards of local governments are not consistent. Some provinces and cities only disclose provincial financial information, and the transparency of local government financial information still needs to be improved. Finally, local governments should disclose their debt risk status. Besides the basic information such as the debt limit and balance of last year, they should regularly release debt risk reports to provide channels for public supervision and enhance public confidence in government financial data.

\subsection{Establishing a debt risk management system for local governments}

The local government debt risk early warning management system can support and protect the effective operation of the debt risk early warning system, including personnel arrangement, power and responsibility division, department coordination and other work. On local government debt risk early warning and dissolve the risk, is the purpose of evading the debt default, so the local government set up a leading group for debt management of local government debt issues on the basis of the daily management, should continue to improve when there is a risk early warning, the relevant departments within the government responsibility, and preparing for the plan. In local debt risk early warning management work, is engaged in the risk early warning work personnel quality has a direct impact on the result of the early warning of efficiency and, therefore should cultivate a group of high 
professional quality staff, clarify the responsibilities of such personnel division of labor, the development of local government debt dynamic real-time tracking, using the advanced methods of risk monitoring and early warning, monitoring and early warning of local government debt risk. At the same time, the central financial department may consider organizing unified training on local debt risk at the national level and unifying the measurement caliber of all indicators in the financial reports of provinces and municipalities.

\subsection{We will improve the mechanism for handling local government debt risks}

Local governments should combine their own conditions and establish a mechanism for early warning of debt risks. When the risk of local government debt is in a mild warning state, although it can be considered that there is less pressure to repay the debt one year later, the management department still needs to pay attention to the changes of the risk. When local government debt risks are in the middle warning stage, active measures should be taken to control and avoid further deterioration of debt risks, such as reducing debt scale, formulating emergency plans for risk treatment and submitting them to the central government for approval. Once debt risks continue to rise, the plans should be implemented immediately to reduce debt risks. When the risk of local government debt is in a state of high alert, it can be considered that the debt repayment pressure of local government is relatively high. At this time, the central government should ask local government to formulate the debt repayment budget in the next three years, and on the basis of safeguarding the principle of fiscal sustainability, reduce other expenditures and raise debt repayment funds. If there is still a debt gap after the implementation of relevant control measures, an application for assistance should be submitted to the central government in a timely manner to prevent systemic risks caused by debt risks.

\subsection{We will establish a solvency reserve system for local governments}

The reserve fund system is usually set up in response to special circumstances. For local government finance, the reserve fund system can play the role of a fund reservoir, disperse the debt repayment burden and reduce the risk of debt default. According to different USES, the solvency reserve system can be divided into two types: comprehensive reserve and special reserve. The comprehensive reserve fund is conducive to the overall planning of local governments, but it lacks effective supervision over the application of various debt funds. The special reserve fund is helpful for local governments to carry out classified supervision on the use of all kinds of debt funds, but it requires local governments to have higher financial capacity and management ability. In service projects such as expressways, electricity and water, local governments can collect revenue by charging users a certain amount of fees. After deducting the expenses needed for operation and maintenance of the projects, part of the funds will be transferred into the debt repayment reserve fund. In addition, the land-use right grant fee is an important source of local government revenue, and the income from state-owned assets contributes objectively to local government revenue, which can be used as a source of debt repayment reserve.

\section{Conclusion}

This paper selects evaluation indexes from three aspects of economic development status, financial status and debt status, USES entropy weight method to determine the weight of indexes, and calculates the comprehensive evaluation indexes of local government debt default rate and debt risk in 30 provinces and cities in China. Results show that in 30 provinces and cities, the local government debt in a state of no warning has seven, in a state of mild warning there were 10 , were in moderate alert has three, there are 10 in a heightened state of alert, close to $80 \%$ of the local governments need to attach importance to debt risk problem, improvement measures in time to avoid the deterioration of debt risk.Overall, the current local government debt risk overall structural control, but there are a small number of provinces and cities of debt risk is not optimistic, the eastern and western areas, for example, must strengthen the existing debt risk control, focus on the scale of recessive debt, in the case of comprehensive debt reasonable growth, local governments can guarantee the stability of its debt structure, rationality, and ahead of the debt risk of the accident.

In view of this situation, this paper believes that the provincial and municipal governments should further strengthen the disclosure of debt information, realize the effective monitoring of debt risk, and enhance public confidence in government financial data. We will establish a local government debt risk management system, set up a local government debt risk management agency, place professional local government debt risk warning staff, and use advanced and scientific methods to give early warning to local government debt. We will improve the debt risk handling mechanism of local governments, and take targeted measures according to the level of their own debt risk early warning, so as to control the debt risk within a safe range to the greatest extent. Establish local government debt - paying reserve system to alleviate local government debt - paying dilemma.

The influencing factors of local government debt risk are complex, and the evaluation indexes selected in this paper cannot reflect all the influencing factors. Since the complete analysis data of 2018 cannot be obtained, the relevant data of 2017 are selected for analysis, and the analysis results are somewhat delayed. The follow-up research can further enrich the evaluation index in the early warning system of local government debt risk and update the research data, so as to improve the comprehensiveness and timeliness of the research results.

\section{References}

1. An Xiumei. Empirical Analysis of contingent Liabilities of local governments [J]. Journal of 
Central University of Finance and Economics,2002(06):40-45.

2. Liu Shaobo, HUANG Wenqing. Research on Hidden Debts of Local Governments in China [J]. Financial Research,2008(09):64-68

3. Wang Meihan. Research on implicit Government Debt Risk in China [J]. Financial and Economic Studies,2002(01):23-30.

4. Wei Rongrong, LI Tiande, Zou Xiaoyong. Estimation and Risk Assessment of PPP implicit Debt of Local Governments in China -- Empirical Analysis based on spatial measurement and KMV Model [J]. Social Science Research,2020(02):66-74.

5. Li Lizhen, AN Xiumei. Hidden Debt of Local Governments: Boundary, Classification estimation and Governance Path [J]. Contemporary Finance and Economics,2019(03):37-47.

6. Wang Xiaoguang, Gao Shudong. Early Warning Evaluation and Control of Local government debt Risk [J]. Contemporary Economic Research,2005(04):53-55.

7. Zhang Zhiping. Grey Assessment and Early Warning of Local Government debt risk in China [J]. Statistics and Decision-making,2011(15):135-138.

8. Shen Yuting, JIN Hongfei. Research on Early Warning System of Local Government Debt Risk in China -- Analysis based on ahP and Entropy Method [J]. Contemporary Finance and Economics, 2019(06):34-46.

9. zhou liang, Liu Yihong. Prevent and resolve the difficulties and countermeasures of the debt risk of local government: a literature review [J/OL]. Financial development research: 1-7 [2020-04-01]. HTTP: / / https://doi.org/10.19647/j.cnki.371462/f.2020.03.008.

10. Gao Hua, ZHANG Xuan. Research on Local Government Debt Risk Assessment: Dynamic System Model and Prediction [J]. Finance and Economics,2020(03):34-44.

11. MAO Jie, Han Ruixue, Xu Junwei. Financial Pressure and Expansion of Local Government Debt -- Quasinatural Experimental Analysis based on Full-gauge Government debt data in Beijing [J]. Comparison of Economic and Social Systems,2020(01):22-33.

12. Guo Yuqing, Xue Qiqi, Jiang Lei. Evolution logic and Transformation Path of Local Government Debt Governance -- And On the Riddle of Local Government Debt Financing in China [J]. Comparison of Economic and Social Systems,2020(01):34-43.

13. minty, song haemorrheological nature. Local government debt scale and risk measurement research [J/OL]. Economy and management review, $2020(01)$ : 73-86 [2020-04-01]. https://doi.org/10.13962/j.cnki.371486/f.2020.01.008.

14. Zhu Deyun, su-fen wang. Local government debt scale and municipal infrastructure investment, efficiency and effect $[\mathrm{J} / \mathrm{OL}]$. Economy and management review, 2020 (01) : 87-98 [2020-04-01]. https://doi.org/10.13962/j.cnki.371486/f.2020.01.009.

15. Wang Zhouwei, ZHAO Qicheng, LI Fangfang. Risk value estimation of Local government debt and its Decomposition application of spatial effect [J]. China Soft Science,2019(12):81-95. 